\title{
Analysing the Pragmatic Content in the Conversation Sections in Indonesian ELT Textbooks
}

\author{
Eka Siswantara ${ }^{1} \&$ Kamisah Ariffin ${ }^{2 *}$ \\ ${ }^{1}$ Pemepek, Pringgarata, Central Lombok Regency, West Nusa Tenggara, Indonesia. \\ ekasiswantara.id@gmail.com \\ ${ }^{2}$ Academy of Language Studies, Universiti Teknologi MARA Pahang, 26400 Bandar Tun Abdul Razak, Pahang, Malaysia \\ kamisah@uitm.edu.my \\ *corresponding author
}

Article history:

Received: 29 May 2021

Accepted: 7 July 2021

Published: 31 July 2021

\begin{abstract}
Pragmatic competence is a core part of communicative competence and has become the main focus of teaching and learning process in today's English language teaching. Thus, it is pivotal to have more of pragmatic materials in English textbooks since they are the major references used in the classroom. This study examined the conversation section in the series of Indonesian ELT textbooks to see whether the pragmatic content as required in the curriculum is fulfilled. Using Searle's speech acts model as the framework, content analysis method was applied by using descriptive approach in analysing the illocutionary acts and forces provided in the textbooks. The findings indicate that despite their occurrences on the textbooks, some of the speech acts provided were low in frequency and lacked variety to develop better pragmatic competence for the students. This has significant implications on the textbook writers in developing content materials for the pragmatic competence.
\end{abstract}

Keywords: Pragmatic competence, Illocutionary acts, Illocutionary forces, ELT Textbooks

\section{Introduction}

Communicative competence has been one of the main focuses of English Language Teaching (ELT). Thus, in the ELT practice, communicative competence is one of the selling points offered to the English learners. Applying communicative competence as the target for ELT requires a comprehensive set of competence covering syntactic, semantic and pragmatic competence. It is a pivotal part of communicative competence, yet, the most intricate one. Pragmatic competence, in general, is considered as having the capability to understand, interpret, as well as convey meaning correctly and appropriately in social communication (Thomas, 1983; 2014). When learners can employ pragmatic in their communication, they can be considered as competent speakers in the language. On the other hand, their lack of pragmatic competence may lead them to misunderstanding and miscommunication (Hymes, 1974). Empirical studies have shown that a large number of foreign language learners were not able to identify the socio-cultural of the language correctly in the context of interaction. As a result, they fail to overcome the gap in understanding native speaker's pragmatic communication.

Despite being an essential element in communicative competence, pragmatic knowledge has not been provided sufficiently in ELT. Eslami-Rasekh (2005) claimed that the English teachers provide insufficient pragmatic knowledge in their teaching materials and little do they emphasize the pragmatic details in their teaching. In the local Indonesian scene, Suryoputro and Suyatno (2017) also found that pragmatics is introduced in a limited extent in ELT textbooks, hardly ever provided as materials taught to EFL students, and still neglected by teachers.

There have been few studies that examined the pragmatic content in the Indonesian ELT textbooks (Inawati (2016), Kusumo and Wardani (2019), and Pramono and Kurniawan (2020). However, the focus of these studies has been limited in terms of the illocutionary acts and forces analysed, as well as the number and level of the textbooks examined. This current research, thus, aims at analyzing more variables in the pragmatic scope with more textbooks for various grades (grades X, XI, and XII) to provide a more comprehensive analysis.

\section{Literature Review}

In today's trend of ELT, communicative competence emerges as the choice to be the main goal of ELT in almost all of the countries in the world. In some curriculum, especially in Indonesia, the model of communicative competence, based on Celce- 


\section{Eka Siswantara, Kamisah Ariffin}

\section{Analysing the Pragmatic Content in the Conversation Sections in Indonesian ELT Textbooks}

Murcia's (2008) framework, is applied as the main competence's goal. One of the important components in this model is the sociocultural competence which refers to the pragmatic competence. The important components in this aspect of competence are: 1) social contextual elements in terms of age, gender, status and social distance of the participants, as well as power relation between them, 2) stylistic appropriateness which may involve politeness strategies, a sense use of genres and registers, 3) cultural factors that knowledge and awareness of cross-cultural differences.

Reigle (2011) argued that the awareness of pragmatic differences that is presented in the classroom would equip the learner to be better in L2 communication when they encounter with the native speaker outside the classroom. In other words, for L2 learners to function well within the target language society, knowledge of language structures is simply insufficient. It is also pertinent to have the knowledge of how to use the language to convey and interpret intended meaning. To acclimate well into the L2 culture, learners must have the ability to accurately comprehend, interpret and use implicative meaning. With this emphasis on and capacity for pragmatic competence seems to be a common denominator among language learners who acclimate easily into the target culture.

Along the same line, Koran and Koran (2017) emphasized the importance of pragmatic competence in regards with EFL learners. They put forward that pragmatic errors can cause serious consequences compared to grammatical errors. For example, a speaker may appear rude or offensive without his/her intention to do so if he/she uses inappropriate style or are not aware of the sociocultural differences. This implies that regardless how perfect the linguistic competence acquired by the learners, when it comes to the lack of pragmatic competence, it will lead to the total communication breakdown and unpleasant experience for both learners and the native speakers. Thus, it is very important to develop EFL learners' pragmatic competence, especially through effective and sufficient learning resources and situations, as usually, like the case in Indonesia where English is almost foreign to most learners, the only exposure to English is the language and materials received in the classroom.

\section{Illocutionary acts}

Illocutionary act demonstrates utterances or expressions that convey certain forces. It is an act to perform some action in utterances such thanking, complimenting, refusing, and requesting, among others. Moreover, illocutionary act also relates to utterances in the association with the act they intend to perform explicitly. Table 1 below describes Searle's (1979) typological system of the illocutionary acts.

Table 1: Illocutionary Act Framework (Searle, 1979)

\begin{tabular}{lc}
\hline Illocutionary Act & Illocutionary Force \\
\hline $\begin{array}{l}\text { Assertives } \\
\text { showing an actual state or affair }\end{array}$ & $\begin{array}{c}\text { informing, asserting, reporting, } \\
\text { announcing, claiming, etc. }\end{array}$ \\
\hline $\begin{array}{l}\text { Directives } \\
\text { conveying attempts to have the listener do } \\
\text { some action }\end{array}$ & $\begin{array}{c}\text { ordering, inviting, advising and } \\
\text { requesting. }\end{array}$ \\
\hline $\begin{array}{l}\text { Commissives } \\
\text { requiring the speaker to be committed to per- } \\
\text { form some actions }\end{array}$ & $\begin{array}{c}\text { promising, warning, guarantee- } \\
\text { ing, refusing and offering }\end{array}$ \\
$\begin{array}{l}\text { Expressives } \\
\text { showing someone's psychological state or } \\
\text { feeling towards the utterances expressed }\end{array}$ & $\begin{array}{c}\text { apologizing, congratulating, } \\
\text { thanking, complimenting }\end{array}$ \\
\hline $\begin{array}{l}\text { Declaratives } \\
\text { showing the connection between the proposi- } \\
\text { tional content and the reality which cause } \\
\text { changes by means of sentences }\end{array}$ & $\begin{array}{c}\text { declaring war, marrying a cou- } \\
\text { ple, firing from employment, sen- } \\
\text { tencing, dismissing }\end{array}$ \\
\hline
\end{tabular}

When performing an interaction, someone who performs illocutionary acts can be successful in conveying the intention or it might fail. To perform the intended act, the context, thus, has to be appropriate. Vanderveken (2009) supported that individuals will outline aspects that conditions that can succeed illocutionary acts from the elements of their force and the propositional content.

\section{Pragmatic Content in ELT Textbooks}

Having looked at the importance of pragmatic competence in ELT, the ideal means to present information on this is through ELT textbooks. Thus, many researchers are concerned with how pragmatic aspects are presented in the textbooks. Delen and Tavil (2010), for example, investigated eleven EFL course books content in Turkey related to requesting, rejecting and complaining. The analysis indicates that request was sufficiently-distributed in the textbooks but it was not the case for the other two speech acts. Along the Copyright (C) The Author(s). All Rights Reserved 
same line, Ren and Han (2016) analysed the pragmatic aspects in ten English language textbooks used in Chinese universities. The study examined on the occurrences of pragmatic information, the treatment of speech acts, and the representation of intralingual pragmatic variation. Not only the textbooks lack provision of pragmatic knowledge with limited range of speech acts, it seems that the speech acts provided is dependent on the authors' intuition. There is a scarcity of metapragmatic information on the speech acts. Furthermore, not much consideration is given to enhance the students' awareness on intralingual pragmatic variation. Hence, this raises concerns on the students' opportunity in developing their pragmatic abilities in interpreting and conveying their intentional illocutionary appropriately.

On the other hand, Baleghizadeh and Rastin (2015) investigated the Top-Notch teachers' books (both first and second editions) for meta-pragmatic content provided. In contrast with the Delen and Tavil (2010) and Ren and Han (2016) studies, the analysis shows that the books offer a variety of meta-pragmatic information that can be utilised by instructors to teach pragmatic aspects of second language use more effectively in the classroom. This shows that some ELT textbooks do contain sufficient pragmatic contents that can assist the teaching of pragmatic competence to the students.

In the local scene, Inawati (2016) analyzed meta-pragmatic information presented in nine local textbooks for grades VII and X in Indonesia. She found that that meta-pragmatic information is presented inadequately in these books. The meta-pragmatic information is mostly limited to one to three speech acts only, such as speech acts for requesting, rejecting, and complaining. In addition, Pramono and Kurniawan (2020) studied the frequency of speech acts of thanking and apologising provided in two Indonesian ELT textbooks; a textbook prescribed and published by the Ministry of National Education and a commercial textbook for grade VII. The results pointed that the speech acts of thanking and apologising have been sufficiently presented in both textbooks analysed. Nevertheless, both textbooks failed to provide various strategies to perform thanking and apologising.

\section{Basic Competence of Indonesian ELT Curriculum 2013}

Based on the ELT Curriculum 2013, there are some basic competences related to speech acts required for the English teaching and learning. The following table shows the basic competences that should be provided in the textbooks according to Curriculum 2013 which are related to speech acts:

Table 2: Basic Competence of Indonesian Curriculum 2013 and speech acts required for grades X, XI, and XII

\begin{tabular}{|c|c|c|}
\hline Grade & Basic Competence in Curriculum 2013 & Speech acts required \\
\hline \multirow[t]{12}{*}{$\mathbf{X}$} & Basic Competence 3.1 \& 4.1 : & Questioning \\
\hline & \multirow{3}{*}{$\begin{array}{l}\text { Introducing and mentioning identity to develop interactional com- } \\
\text { munication with others }\end{array}$} & Informing \\
\hline & & Congratulating \\
\hline & & Praising \\
\hline & Basic Competence $3.2 \& 4.2$ : & Planning \\
\hline & \multirow{2}{*}{$\begin{array}{l}\text { Congratulating and complimenting to develop interactional com- } \\
\text { munication with others }\end{array}$} & Describing \\
\hline & & Thanking \\
\hline & \multirow{3}{*}{\multicolumn{2}{|c|}{$\begin{array}{l}\text { Basic Competence } 3.3 \mathbf{8} \mathbf{4 . 3} \text { : } \\
\text { Telling and asking about intentions of doing something to develop } \\
\text { interactional communication with others }\end{array}$}} \\
\hline & & \\
\hline & & \\
\hline & \multicolumn{2}{|l|}{ Basic Competence $3.4,4.4 .1, \&$ 4.4.2 } \\
\hline & \multicolumn{2}{|l|}{$\begin{array}{l}\text { Describing or presenting information about a particular place and } \\
\text { a historical building }\end{array}$} \\
\hline \multirow[t]{10}{*}{$\mathbf{X I}$} & Basic Competence $3.1 \& 4.1$ & Questioning \\
\hline & \multirow{3}{*}{$\begin{array}{l}\text { Asking and giving information related to suggestion and offer to } \\
\text { develop interactional communication with others }\end{array}$} & Informing \\
\hline & & Suggesting \\
\hline & & Offering \\
\hline & Basic Competence $3.2 \& 4.2$ & Asserting \\
\hline & \multirow{3}{*}{$\begin{array}{l}\text { Asking and giving information related to personal opinion and } \\
\text { thought to develop interactional communication with others }\end{array}$} & Stating opinion \\
\hline & & Inviting \\
\hline & & Accepting \\
\hline & Basic Competence 3.3 \& 4.3 & Refusing \\
\hline & $\begin{array}{l}\text { Inviting for school/work event in the form of formal invitation to } \\
\text { develop interactional communication with others }\end{array}$ & \\
\hline
\end{tabular}


Analysing the Pragmatic Content in the Conversation Sections in Indonesian ELT Textbooks

\begin{tabular}{cll}
\hline Grade & Basic Competence in Curriculum 2013 & Speech acts required \\
\hline XII & Basic Competence 3.1 \& 4.1 & \\
& $\begin{array}{l}\text { Offering services and responding to it to develop interactional } \\
\text { communication with others }\end{array}$ & Offering \\
& Questioning \\
& Informing \\
& Basic Competence 3.1 \& 4.1 & Suggesting \\
& Asking and giving information related to personal information, ed- & Commanding \\
ucation background or work experiences to develop interactional & Accepting \\
& communication with others & Refusing \\
& Thanking \\
& Basic Competence 3.5 \& 4.5 & Stating opinion \\
& Making conditional sentences followed by suggestion and imper- & Stating surprise \\
ative to develop interactional communication with others & \\
\hline
\end{tabular}

Based on the curriculum requirement and Inawati's and Pramobo and Kurniawan findings, the researchers were motivated to investigate the pragmatic information presented in the local Indonesian ELT textbooks at various levels and to see whether the pragmatic content in the books properly and sufficiently provide pragmatic information that is required to develop students' pragmatic competence as prescribed by the curriculum.

\section{The Study}

The main objectives of this study were to analyse the types and frequency of illocutionary acts and illocutionary forces for the fulfillment of the language functions as prescribed by the Basic Competence Curriculum 2013 in the three ELT textbooks for Grades $\mathrm{X}, \mathrm{XI}$ and XII. Thus, the research questions formulated for this study were:

i. What are the types of illocutionary acts and illocutionary forces for the fulfillment of the language functions as prescribed by the Basic Competence Curriculum 2013 in the three ELT textbooks for Grades X, XI and XII?

ii. What is the frequency of the illocutionary acts and illocutionary forces provided in conversation sections of the three ELT textbooks for Grades X, XI and XII?

iii. How are contextual and meta-pragmatic information presented in the textbooks?

This study applied content analysis by using descriptive approach. The focus of the study was the pragmatic content in the series of Indonesian ELT textbooks entitled Bahasa Inggris untuk SMA/MA/SMK/MAK Kelas X (English for High School Grade X), Bahasa Inggris untuk SMA/MA/SMK/MAK Kelas XI (English for High School Grade XI), and Bahasa Inggris untuk SMA/MA/SMK/MAK Kelas XII ((English for High School Grade XII), issued by the Indonesian Ministry of Education. Grades X, $\mathrm{XI}$, and XII were chosen as these are the highest level for ELT learning for school level, thus, more language functions are supposed to be taught to enhance students' pragmatic competence. The data were gathered from the interactions in the conversation sections of the textbooks. The data collection was conducted through careful analysis of the conversations in the textbooks to answer the research questions.

The analysis on the frequency of illocutionary acts and illocutionary forces in the textbooks was carried out by following Searle's (1979) speech acts model. The data were treated quantitatively in terms of frequency counts for each category, and later converted into percentage. As this study investigates the pragmatic aspects of conversation, the data were analysed by applying pragmatic identity technique (Sudaryanto, 1993). This technique was employed in identifying linguistic units in step with their linguistic units and the effects performed by the speaker or according to the reaction and effect of the hearer when the utterances uttered or conveyed (Kusumo \& Wardani, 2019). The illocutionary acts were categorised by using the Searle's (1979) concept of speech acts, which was also supported by Yule (1996), Mey (2001), and Cutting (2002). Two inter-raters who were the experts in the field were consulted to ensure the validity of the analysis. Descriptive analysis was used to explain and discuss the findings.

The contextual and meta-pragmatic information analysed in this study were in terms of any kind of explicit information that explains context of the utterances and the aspects of pragmalinguistic (the relationship between form and function) and sociopragmatic (the relationship between form and social considerations of language use). To capture the contextual and meta-pragmatic 
International Journal of Modern Languages and Applied Linguistics e-ISSN: 2600-7266

information in the textbooks, the analysis on the conversation and the presentation of the language form and function was conducted for each chapter in the three textbooks. 


\section{Findings}

\section{Analysing the Pragmatic Content in the Conversation Sections in Indonesian ELT Textbooks}

The findings of this study are presented based on the research questions which are relative to i) the types of illocutionary acts and illocutionary forces for the fulfillment of the language functions as prescribed by the Basic Competence Curriculum 2013 in the three ELT textbooks, ii) the frequency of the illocutionary acts and illocutionary forces provided in textbooks, and iii) the presentation of contextual and meta-pragmatic information in the books.

\section{Types of Illocutionary Acts and Illocutionary Forces Provided in the ELT Textbooks as Prescribed in the Basic Compe-} tence Curriculum 2013

In general, the analysis shows that the ELT textbooks for grades X, XI and XII contain the four types of illocutionary acts prescribed by the curriculum, which are Directives, Assertives, Expressives, and Commissive. The following section describes and illustrates these illocutionary acts and the illocutionary forces as presented in the textbooks.

\section{Directives}

The concept of directives according to Searle (1979) is the utterances indicating attempts to get someone to do something. Thus, certain utterances which either explicitly or implicitly show invitation or suggestion for the hearer to do something or even in a bolder attempt such as insisting something to be done by the hearer are part of this category. Moreover, Searle narrowed it down into the specific follow up action expected from directives utterances which is the hearer will do some future action as what the speaker want, wish or desire (Searle, 1979, p.13). In line with Searle, Mey (2001) stated that the illocutionary point of directives is imperatives in which the utterances lead to how the world fits the words, meaning that the utterances change the world in accordance to what the speaker wishes (Mey, 2001, p.120). Therefore according to Searle (1979, p.14), the verbs indicating this classification are 'ask, order, command, request, beg, plead, pray, entreat, and also invite, permit, advise, dare, defy and challenge'.

In the Curriculum 2013, the illocutionary forces prescribed for the directives illocutionary act for grades X, XI, and XII are Questioning, Commanding, Inviting and Suggesting. Based on Searle's (1979) and Mey's (2001) these illocutionary acts are evidently provided in all of the three textbooks analysed.

\section{Questioning}

Questioning is an illocutionary force that expresses the speaker's intention to make the hearer reply or respond. Question is part of directives since it is the speaker's attempt to get hearer to respond (Searle, 1979, p.14). Questioning is quite easily identified since the utterances are syntactically familiar both for teacher and students. Learning interrogative sentences are the very basic process in learning language, thus, the utterances found in the textbooks mostly general questions with interrogative structure in the form of yes/no questions and WH- Questions, such as:

Riri : It will be a long weekend soon. Do you have any plans?

Santi : Uhm, I'm not sure. I don't have any idea yet. I think I might stay at home.

(Grade X, p.40)

\section{Commanding}

Commanding expresses the utterance for asking or ordering the hearer to do something in direct way. Commanding is mostly identified in the form of imperative sentences. It usually comprises imperative verbs which in English, it is typically formed using the base verb with no subject with an exclamation mark/point (!) as a typical punctuation for the marker. The example of the commanding utterances found in the textbooks is as follow:

$\begin{array}{lll}\text { Ami } & \text { Riza, look! That heroic monument stands high and strong. } \\ \text { Riza } & \text { Hmm... It is a remembrance for us to our heroes' struggle on this country. }\end{array}$

(Grade X, p.129)

\section{Inviting}

Inviting is the act committed by the speaker to propose a future action and then tries to get the hearer to attend or participate in that action. The following data are the examples of utterances found for inviting category. Invitation is mostly uttered in direct way in the form of interrogative and declarative sentence, the following example convey inviting in the interrogative form: 
Bayu : No. We plan to go fishing in a lake near my uncle's house. Would you like to come with us?

Santi : Fishing? That sounds great. But I would rather stay at home than go fishing.

(Grade X, p.40)

\section{Suggesting}

A suggestion is an utterance in which proposes an idea that best for the listener so that he/she can consider doing it. Following Thomson and Martinet (2001, p.251), Al-aadeli (2014) elaborated that suggestions can be expressed through several language strategies, one of the strategies is First person suggestions with 'let's' or 'shall'. The example of this strategy is captured in the following example in the textbook:
B : Great! What movie do you want to watch?
A : Let's watch "Ring"
B : I would rather not, I am not much into horror movies. How about Peanuts?
A : Ok, let's go. When do you want to go?

(Grade XI, p.2)

\section{Assertives}

Assertive acts express statement that the speaker believes as the case. Cutting (2002, p.17) mentioned that describing, claiming, hypothesising, insisting and predicting, etc. are among the acts in this category. According to Curriculum 2013, the required speech acts for this category are Informing, Describing, Stating Opinion, and Asserting.

\section{Informing}

Informing is an illocutionary force to convey information. In general, it is the act to give information or supply knowledge about particular things to other people. The following examples are the utterances from the three textbooks analyzed under this category:

\section{Riza : When I was in Junior High School, my school held a program called "Keep our city clean and green!"}

Ami : What did you do?

\section{Stating Opinion}

(Grade X, p.129)

Stating an opinion is an illocutionary force used to tell own thoughts, ideas, or opinions rather than facts to the listener. Several utterances showing opinion are presented as follows:

Indah : Listen, the article says that the size can be 10 meters long. It's as big as a school bus!

Lyla : : Wow! I think a giant squid is very unique.

(Grade XII, p.30)

A : I don't agree with you, a little bit teasing here and there is acceptable

B : I am of the opinion that no one has any right to harass or make people feel inferior. No one should have that kind of power

(Grade XI, p.19)

\section{Describing}

Describing is an expression to describe what someone or something is like. It is an illocutionary force to represent or give an account of in words. Several utterances under the category of describing are presented as follow:

Indah : Look at this one. It's a giant squid.

Lyla : Have a look at the size! It's very big!

(Grade XII, p.30)

Ami : Riza, look! That heroic monument stands high and strong.

Riza : Hmm.... It is a remembrance for us to our heroes' struggle on this country. 
Asserting is an illocutionary force that expresses attitude and belief. MacFarlane (2011) stated that to assert means to express attitude in the sense that the speaker expresses the belief and the intention that the hearer believes that utterance. Moreover, this attitude is the way the speaker expresses his/her reflexive intention so that the hearer would take the utterance as reason to think that the speaker has that attitude (MacFarlane, 2011). The following dialogues are the examples found as asserting:

A : Really? It sounds scary.

B : it is! If we do not educate people about the effects of smoking, there will be a lot of people suffering from this disease.

(Grade XI, p.75)

A : hey stop! you are getting too serious!

B : yes! you should be serious about it as well. I would like to point out that bullying is everyone's problem and responsibilities. If you condone bullying in any way, shape or form it means you are taking part in it whether it is directly or indirectly by being silent.

(Grade XI, p.19) 
International Journal of Modern Languages and Applied Linguistics

e-ISSN: 2600-7266

\section{Expressives}

Searle (1979) stated "the illocutionary point of this class is to express the psychological state specified in the sincerity condition about a state of affairs specified in the propositional content". Cutting (2002) elaborated that the expressive acts are the utterances that state what the speakers feel. She, then, mentioned some of the examples of this acts like apologizing, praising, congratulating, deploring, and regretting (Cutting, 2002, p.17). Congratulating, Thanking, Praising, and Stating surprise are the illocutionary forces required to be taught in high school level. The details of these illocutionary forces are as follows:

\section{Congratulating}

Congratulating is an illocutionary force that expresses the joy in the success or good fortune. The following dialogues are the examples of congratulating presented in the textbook:

Samuel : Alif, congratulations. You deserved it, man.

Alif : Thank you very much. This is because you always help me.

Sinta : I am very happy for you, Alif. Now, that you are the director of the company, I believe the company will develop even faster.

(Grade X, p.23)

\section{Thanking}

Thanking is the speaker's expression of gratitude about what the hearers do or say. Following Jautz (2008), Yusefi et al. (2015) pointed out that thanking expressions are uttered when a speaker wishes the addressee to realize his/her gratitude towards what the addressee has said or done to the speaker. These are the examples of thanking acts presented in the textbooks:

Eny : Please accept my warmest congratulations, Sir.

Alif : It's very kind of you to say so. Thank you.

Bintari : I must congratulate you on your success.

Alif : Thank you very much for saying so.

(Grade X, p.23)

\section{Praising}

Praising is an illocutionary force considered as polite expression of praise or admiration uttered by the speaker to the hearer. These are the examples of praising found in the textbooks:

\section{A : What a wonderful performance! \\ B : Thank you.}

(Grade X, p.34)

Zahra : It got Grade A from the National Accreditation Body.

Raisa : Wow! That's terrific. We should be very proud.

(Grade XII, p.45)

Stating Surprise

Stating surprise contains utterances that express the speakers' feeling of shock. The following data are some of the examples found in the textbook:

B : did you know that smoking is one of the main causes of sickness in smokers? for example:

1. Smoking weakens the lungs due to which there is a build up of poisonous substances

2. Smoking causes heart attacks coma Strokes coma ulcers.

A : Really? It sounds scary. 
Indah : Listen, the article says that the size can be 10 meters long. It's as big as a school bus!

Lyla : Wow! I think a giant squid is very unique.

(Grade XII, p.35)

\section{Commissives}

Searle (1968) stated that "Commissives are those illocutionary acts whose point is to commit the speaker (in varying degrees) to some future course of action" (p.4). In addition, Cutting (2002, p. 17) defined that commisives comprises acts in which the utterances express the commitment of the speaker to future action. She added that some of the acts under this category are promising, offering, threatening, refusing, vowing and volunteering. The illocutionary forces required under the commissives acts are Refusing, Accepting, Planning and Offering. Further discussion about each types of illocutionary forces are presented below:

\section{Refusing}

Refusing as a speech act is the way hearer expresses his/her wish not to accept, or decline a request, invitation or offer from the speaker. The following data are the refusing utterances provided in the textbooks:

Bayu : No. We plan to go fishing in a lake near my uncle's house. Would you like to come with us? Santi : Fishing? That sounds great. But I would rather stay at home than go fishing.

(Grade X, p.40)

Soepriatmadji (2010) stated that according to Brown and Levinson (1987) Refusing can be considered as a Face-Threatening Act (FTA). Thus, the tendency of the interlocutors in expressing refusing is by using language strategies like indirect refusal or polite expression so that the disharmony and discomfort feeling between the interlocutors can be minimized. Some of the politeness strategy for refusal is presented in the above dialogue, such as how the interlocutor expressed refusal in the first dialogue by saying "that sounds great. But I would rather stay at home than go fishing”, the way that the interlocutor appreciates the invitation by saying "that sound great" might minimize the discomfort for both interlocutors.

\section{Accepting}

Accepting is an illocutionary force that express the acceptance of the offers, applications, suggestion or invitations. Some of the data are presented below:

$\begin{array}{ll}\text { A } & : \text { How about in the afternoon? } \\ \text { B } & : \text { Great! What movie do you want to watch? }\end{array}$

(Grade XI, p2)

This dialogue shows acceptance of the invitation. In this case utterance "great!" expressed by B implied the response of acceptance for A's invitation.

\section{Planning}

Planning is an act to express a commitment of the speaker about things that he/she would do in the future. The examples are presented below:

A : I am going to do my biology project at the library after school. Rina, are you going to do that today, too?

B : Yes. I am going to do it today. The sooner we finish it the better. We can go to the library together.

(Grade X, p.45)

Wilbur : Our father has asked us not to fly together. He said it's for the safety reason.

Orville : Yes, we will continue making more experiment so that airplane will be available for everyone soon.

(Grade X, p.97) 
International Journal of Modern Languages and Applied Linguistics

e-ISSN: 2600-7266

Both dialogues above showed the interlocutors' plan in the future that is clearly shown from the use of future tense. This basic form of the use of be going to and will in stating future plan is some of the essential language forms taught for EFL learners.

\section{Offering}

Offering is an illocutionary force of asking the addressee to find out if he/she might want to do or have something. The logical form of an offer is that the utterance commits the speaker to perform a certain course of action if it is accepted by the hearer and the offer becomes binding only if it is accepted. The example below clearly shows the offer and also the acceptance or refusal expressed by the interlocutors.

\section{A : Would you like any help? \\ B : Yes, please I would appreciate it \\ A : Tell me what I can do and I will start right away \\ B : Thank you, you are an angel}

(Grade XI, p.3)

\section{Frequency of Illocutionary Acts and Illocutionary Forces in the Indonesian ELT Textbooks}

The analysis indicates that all of the speech acts required for grades X, XI and XII are provided in the textbooks, except 'refusing' which is not presented at all in the grade XII textbook. However, the analysis also shows that the speech acts provided are at varying degree, with some at low frequency. The following section presents the frequency of the speech acts as provided in each of the textbooks.

\section{Grade X Textbook}

Table 3 below shows the analysis of the types and frequency of illocutionary acts and illocutionary forces in the grade X textbook.

Table 3: Frequency of Illocutionary Acts and Illocutionary Forces in Grade X Textbook

\begin{tabular}{llcc}
\hline Illocutionary Acts & Illocutionary Forces & Frequency & Total \\
\hline Directives & Questioning & $28(33.7 \%)$ & $28(33.7 \%)$ \\
\hline \multirow{2}{*}{ Assertives } & Informing & $14(16.9 \%)$ & $16(19.3 \%)$ \\
& Describing & $2(2.4 \%)$ & \\
\multirow{2}{*}{ Expressive } & Congratulating & $5(6.0 \%)$ & $35(42.2 \%)$ \\
& Thanking & $18(21.7 \%)$ & \\
\hline Commissives & Praising & $12(14.5 \%)$ & $4(4.8 \%)$ \\
\hline & Planning & $4(4.8 \%)$ & $\mathbf{8 3 ( 1 0 0 \% )}$ \\
\hline
\end{tabular}

As illustrated by the data, the total of all speech acts utterances provided in the grade $\mathrm{X}$ textbook is 83 . The book provides 28 utterances $(33.7 \%)$ of the directive illocutionary act with illocutionary forces of Questioning. Meanwhile, the assertives act shares 16 utterances $(19.3 \%)$ of the illocutionary forces of 'informing' and 'describing' with $14(16.9 \%)$ and $2(2.4 \%)$ utterances respectively. The expressive act provides 35 utterances or $42.2 \%$ of the illocutionary forces of 'congratulating' with 5 utterances (6.0\%), 'thanking' with 18 utterances $(21.7 \%)$, and 'praising' with 12 utterances (14.46\%). The least percentage among the 4 illocutionary acts category is commissive, which only provides 4 (4.82\%) with the illocutionary force of 'planning'.

\section{Grade XI Textbook}

On the whole, 39 utterances containing the illocutionary acts and forces prescribed by the curriculum found in the grade XI textbook. Table 4 shows the detailed analysis of the types and frequency of illocutionary acts and illocutionary forces.

Table 4: Frequency of Illocutionary Acts and Illocutionary Forces in Grade XI Textbook 
Eka Siswantara, Kamisah Ariffin

Analysing the Pragmatic Content in the Conversation Sections in Indonesian ELT Textbooks

\begin{tabular}{|c|c|c|c|}
\hline Illocutionary Acts & Illocutionary Forces & Frequency & Total \\
\hline \multirow{3}{*}{ Directives } & Questioning & $10(25.6 \%)$ & \multirow{3}{*}{$18(46.2 \%)$} \\
\hline & Inviting & $5(12.8 \%)$ & \\
\hline & Suggesting & $3(7.7 \%)$ & \\
\hline \multirow{3}{*}{ Assertives } & Informing & $1(2.6 \%)$ & \multirow{3}{*}{$8(20.5 \%)$} \\
\hline & Stating Opinion & $5(12.8 \%)$ & \\
\hline & Asserting & $2(5.1 \%)$ & \\
\hline Expressive & Thanking & $1(2.6 \%)$ & $1(2.6 \%)$ \\
\hline \multirow{4}{*}{ Commissives } & Refusing & $3(7.7 \%)$ & \multirow{3}{*}{$12(30.8 \%)$} \\
\hline & Accepting & $6(15.4 \%)$ & \\
\hline & Offering & $3(7.7 \%)$ & \\
\hline & & TOTAL & $39(100 \%)$ \\
\hline
\end{tabular}

The analysis indicates that there is $46.2 \%$ of the directive illocutionary act with 18 utterances. These 18 utterances consist of 10 illocutionary force of 'questioning' (25.6\%), 5 of 'inviting' (12.8\%), and 3 of 'suggesting' (7.7\%). Meanwhile, 20.5\% of the utterances are identified as assertive acts, consisting of 8 utterances of which 1 is of 'informing' (2.6\%), 5 of 'stating opinion' (12.8\%), and 2 of 'asserting' $(5.1 \%)$. As for the illocutionary act of expressive, there is only one illocutionary force prescribed in the curriculum 2013 which is thanking. Only one utterance appears as the example in the book, making it only $2.56 \%$ of all utterances for this category. 12 utterances or $30.8 \%$ for the commissive act are found in the textbook, consisting of 3 of 'refusing' ( $7.7 \%$ ), 6 of 'accepting' (15.4\%), and 3 of 'offering' (7.7\%).

\section{Grade XII Textbook}

As in the grade X and XI textbooks, the analysis of the grade XII book also shows that all the illocutionary acts and illocutionary forces as prescribed in the curriculum are accounted for. Table 5 shows the details of the types and frequency of illocutionary acts and illocutionary forces provided in the grade XII textbook.

Table 5: Frequency of Illocutionary Acts and Illocutionary Forces in Grade XII Textbook

\begin{tabular}{|c|c|c|c|}
\hline Illocutionary Acts & Illocutionary Forces & Frequency & Total \\
\hline \multirow{3}{*}{ Directives } & Questioning & $25(32.9 \%)$ & \multirow{3}{*}{$46(60.5 \%)$} \\
\hline & Commanding & $7(9.2 \%)$ & \\
\hline & Suggesting & $14(18.4 \%)$ & \\
\hline \multirow{2}{*}{ Assertives } & Informing & $10(13.2 \%)$ & \multirow{2}{*}{$13(17.1 \%)$} \\
\hline & Stating Opinion & $3(4.0 \%)$ & \\
\hline \multirow{2}{*}{ Expressive } & Thanking & $6(7.9 \%)$ & \multirow{2}{*}{$12(15.8 \%)$} \\
\hline & Stating Surprise & $6(7.9 \%)$ & \\
\hline \multirow{4}{*}{ Commissives } & Accepting & $3(4.0 \%)$ & \multirow{3}{*}{$5(6.6 \%)$} \\
\hline & Refusing & $0(0 \%)$ & \\
\hline & Offering & $2(2.6 \%)$ & \\
\hline & & TOTAL & $76(100 \%)$ \\
\hline
\end{tabular}

The data indicate that the book contains 76 utterances of all the of illocutionary acts of directives, assertives, expressives and commissives, and their illocutionary forces. The total of the directives acts is 46 utterances or $60.5 \%$, with $25(32.9 \%)$ utterances representing the 'questioning' force, 7 (9.2\% of 'commanding', and $14(18.4 \%)$ of 'suggesting'. The assertives act comes with the frequency of 13 utterances (17.1\%) with 2 required illocutionary forces: 'informing' with 10 utterances (13.2\%) and 'stating opinion' with 3 utterances (4.0\%). Expressive act on the whole provides 12 (15.8\%) with the illocutionary forces of 'thanking' and 'stating surprise' offering $6(5.4 \%)$ utterances each. Finally, the illocutionary act of commissives consists of $5(6.6 \%)$ utterances. The analysis shows that there are only two illocutionary forces provided in this book instead three as prescribed in the curriculum. It is found that there are $3(3.95 \%)$ utterances of 'accepting and 2 utterances of 'offering' $(1.8 \%)$. There is none of 'refusing' despite being required in the curriculum.

\section{The Presentation of Contextual and Meta-pragmatic Information in the Textbooks}


International Journal of Modern Languages and Applied Linguistics

e-ISSN: 2600-7266

\section{Contextual Information}

The analysis indicates that the explanation regarding the context and the setting is often provided in most of the conversation section in all the textbooks. One of the examples of this explanation is as follows: 
The following is an example of a conversation between Edo and Slamet who meet for the first time in a party like in picture 1.5. They introduce themselves to each other to know their acquaintance better. Read the dialog silently first. Pay attention to how to introduce self. Discuss the expressions used with your classmate sitting next to you. Then act out pretending to be Edo and Slamet who introduce themselves to each other.

(Grade X, p.17)

Such information is helpful for the learners to understand the context of the conversation, so that when the students learn the conversation, they could refer that to the context of the conversation to comprehend the language functions required. However, despite the context and setting provided in each conversation, the conversation itself lacks the alternative for the language strategy which ideally can be expanded to the pragmatic aspects of the language use such as the degree of formality or expressions as a strategy for opening the conversation when meeting new people (if the topic is introduction).

\section{Semantic and syntactic information}

The analysis suggests that semantic and syntactic information is stressed upon in the conversation section in the three text books. Most of the information provided focuses on the semantic and syntactic aspects of the language form. The examples below illustrate the typical information found in the books for introducing the new language form or expression.

Did you notice that in all the sentences you found be (am, is, are, was, or were) and past participles (V-3)? Those sentences are called passive sentences. Study the following examples to see how passive sentences are formed from active ones.

(Grade XII, p.67)

Suggest means to give a suggestion that is to introduce or purpose an idea or a plan for someone consideration. Suggestions are abstract and can be in form of advice, solution, plan and idea. It can be accepted or refused. Social function: to facilitate interpersonal communication between people.

(Grade XI, p.4)

In self-introduction and also in other communication activities, pronouns are frequently used to prevent unimportant repetition. Pronoun is a word that takes the place of a noun, such as: I, you, me, it, they, we, she, him, us..

(Grade X, p.11)

\section{Meta-pragmatic information}

Information related to the pragmatic aspect of the language function is rather scarce in the textbooks analysed. Although some speech acts are discussed in terms of the pragmalinguistic and sociopragmatic aspects, there is no further explanation on metapragmatic instruction that can help students choose and convey the illocutionary force appropriately. Examples found in the books include:

Compliment is an expression to appreciate or praise other people. Compliment is useful to give encouragement so that people will keep on doing their best and even improve their performance. When to express compliment:

- On daily basis,

- When someone has done his/her best,

- When you visit someone's house for the first time,

- If you notice something new about someone's appearance.

(Grade X, p.33)

Expressing opinions:

Less Formal: I'd say ... It seems to me ... I think ... I reckon ... I feel ...

Formal: Personally, I consider/believe... In my view... In my opinion... To my mind...

(Grade XII, p.31) 
International Journal of Modern Languages and Applied Linguistics

e-ISSN: 2600-7266

\section{Discussion}

The theoretical models of L2 posit that communicative competence requires pragmatic competence (Bachman \& Palmer, 2010; Canale \& Swain, 1980; Roever, 2009). This study was undertaken with the consideration that textbooks should address the requirement of the educational plan for educators. Thus, the study has investigated to what extent the pragmatic elements are incorporated in the series of Indonesian ELT textbooks for Grades X, XI and XII.

The findings indicate that, in general, the ELT textbook series succeeds quite well in providing the pragmatic content as required in the curriculum. All the illocutionary acts and illocutionary forces prescribed by the curriculum, except for one illocutionary force that was missing in the grade XII book, were provided. This presents a serious concern to the development of communicative competence as teachers may not be aware of the missing component if it is not included in the book. As put forward by Glaser (2018), instructors may require ideas and direction on the most effective method to present certain concepts and they cannot be expected to do this if the components are missing from the teaching resources.

The main concern of the finding of this present study is the infrequent amount of pragmatic information presented in the three books examined. The results have shown that frequency of pragmatic occurrences in the books varies to a certain extent $(83,39$ and 76 in grade X, XI and XII textbooks respectively). Obviously, grade XI textbook proves to be lacking of the pragmatic content as compared to grade X and XII. This presents a major concern as all students nationwide will be using the same textbooks as learning resources. Such infrequent amount of content may not provide them with the necessary knowledge of pragmatic forms. This is in line with several studies that examined the pragmatic content of ESL/ELT/EFL textbooks and found that lack of consistency in terms of scope and treatment of pragmatic content as a major problem (Diepenbroek and Derwing, 2013; Ren and Han, 2016; O'Keeffe et al., 2011). Diepenbroek and Derwing (2013) postulated that this may leave students with inadequate information and knowledge of pragmatic forms.

Another concern is that teachers will have less choice in presenting the competence in the classroom if the pragmatic content provided in the textbooks is infrequent. The findings suggest that there is a need for the teachers to supplement the textbooks with additional learning resources and activities that can enhance the development of pragmatic competence. However, this may call for the enhancement of instructors' ability to include pragmatics contents in their classroom teaching.

The results have shown that most of the contexts provided in every conversation are limited to the background information of the interlocutors and the setting only. Meta-pragmatic information is rarely discussed in the three textbooks. The most relatable aspect of pragmatic found in the textbooks is the explanation of social function of certain speech acts or degree of formality of the speech acts. However, the explanation is only in terms of the list of expressions considered as formal or informal without any further explanation about what contexts are considered formal or informal. Moreover, there is no conversation example to show the communication strategy in a formal context or informal context. Furthermore, in most of speech acts discussed in the textbooks, the explanation is more on the semantic and syntactic aspects showing only the lists of expressions with the emphasis on the grammatical structure. Therefore, it can be concluded that contextual and meta-pragmatic information are not adeequately presented in the three textbooks. Thus, the explanation of context for the conversation in this textbook may not be fully helpful in terms of pragmatic aspect since there is no exploration on the example or alternative of the language use in different context and setting that can help students acquire communicative strategy. As argued by Ren and Han (2016, p.8), "even if expressions are arranged according to formality, no metapragmatic instruction is provided in terms of explanation. It is therefore concerning to consider how students in EFL contexts could develop their pragmatic abilities to expand their pragmalinguistic repertoire and fine-tune speech act realizations to appropriately convey their intentional illocutionary force".

\section{Conclusion}

Textbooks are important in any study programme. Not only they provide structure to the teaching and learning process, they also guarantee similar content for students in different classes, schools or regions if they are adopted for national use. Thus, Richards (2001) put forward that textbooks allow teachers time to focus on teaching rather than material development.

This study has shown that the grades X, XI and XII textbooks examined do provide all of the speech acts prescribed by the Indonesian ELT curriculum, except for 'refusing' which is not presented at all. The results also indicate discrepancies in the amount of provision of the speech acts in the books. This has significant implications for textbook writers and material designers or developers. Such lack of a speech act and the varying provision of speech acts in the book indicate the inefficiency of the books and may limit the development of pragmatic competence among the students. If teachers solely depend on the textbooks as the teaching resources, the missing speech act and the inequality of the speech act among the grades may not help to develop the students' competence. As argued by Elliot and Woodward (1990), textbooks are influential as they describe what is most learnt by students. 
Eka Siswantara, Kamisah Ariffin

Analysing the Pragmatic Content in the Conversation Sections in Indonesian ELT Textbooks

On the other hand, if teachers need to supplement their teaching materials, they will have to spend more time on developing materials rather than focusing on classroom teaching.

\section{Acknowledgment}

The authors would like to thank Universitas Ahmad Dahlan, Yogyakarta, Indonesia and Universiti Teknologi MARA Pahang for the experience in the Joint-Thesis Writing programme. 
International Journal of Modern Languages and Applied Linguistics

e-ISSN: 2600-7266

\section{References}

Al-aadeli, N. M. (2014). Suggestion and Advice in Three Selected Plays. Journal of Educational and Practice, 5(4), 14-25.

Bachman, L. and Palmer, A. (2010). Language Assessment in Practice. Oxford: Oxford University Press.

Baleghizadeh, S., \& Rastin, H. (2015). Investigating Metapragmatic Information in Language Teachers' Books: A Case of Top Notch. International Journal of Society, Culture \& Language, 3(2), 47-56.

Bashir, M. (2017). Bahasa Inggris Kelas XI SMA/MA/SMK/MAK. Jakarta: Pusat Kurikulum dan Perbukuan, Balitbang, Kemendikbud.

Canale. M. \& Swain, M. (1980). Theoretical Bases of Communicative Approaches to Second language Teaching and Testing. Applied Linguistics 1(1): 1-48.

Celce-Murcia, M. (2008). Rethinking the role of communicative competence in language teaching. In Intercultural language use and language learning (pp. 41-57). Springer, Dordrecht.

Cutting, J. (2002). Pragmatics and Discourse: A Resource Book for Students. Routledge.

Delen, B., \& Tavil, Z. M. (2010). Evaluation of four coursebooks in terms of three speech acts: Requests, refusals and complaints. Procedia-Social and Behavioral Sciences, 9, 692-697.

Diepenbroek, G. L., Derwing, M. T. (2013). To what extent do popular ESL textbooks incorporate oral fluency and pragmatic development? TESL Canada Journal/Revue TESL du Canada, 30(7), 1-20.

Elliott, D.L., \& Woodward, A. (1990). Textbooks and schooling in the United States. 89th Yearbook the National Society for the Study of Education. Chicago, IL: University of Chicago Press.

Eslami-Rasekh, Z. (2005). Raising the pragmatic awareness of language learners. ELT Journal, 59(3), 199-208.

Hymes, D. (1974). Foundations in Sociolinguistics: An Ethnographic Approach. University of Pennsylvania Press.

Inawati, I. (2016). The Pragmatics of Greetings Reflected in the Textbooks for Teaching English as a Foreign Language in Indonesia. Ahmad Dahlan Journal of English Studies, 3(2), 1.

Jautz, S. (2008). Gratitude in British and New Zealand Radio Programmes: Nothing but Gushing? In K. P. Schneider and A. Barron. (eds). Variational Pragmatics: A focus on regional varieties in pluricentric languages. Amsterdam: John Benjamins, 141-178.

Jakupčević, E., \& Portolan Ćavar, M. (2021). An analysis of pragmatic content in EFL textbooks for young learners in Croatia. Language Teaching Research. 1-20

Koran, E., \& Koran, S. (2017). Pragmatic Competence as an Integral Part of EFL Teaching. International Journal of Social Sciences \& Educational Studies, 4(3), 87-93.

Kusumo, D. W., \& Wardani, D. K. (2019). An Analysis of Illocutionary Acts in Spoken Dialogs in an English Textbook. ELT Echo: The Journal of English Language Teaching in Foreign Language Context, 4(1), 147-157.

MacFarlane, J. (2011). What Is Assertion? Assertion: New Philosophical Essays, May 2008, 1-25.

Mey, J. L. (2001). Pragmatics: An Introduction, 2nd Edition. Blackwell.

O’Keeffe, A., Clancy, B. \& S. Adolphs. (2011). Introducing Pragmatics in Use. London: Routledge.

Pramono, S. A., \& Kurniawan, E. (2020). A Micro Analysis Study of Pragmatic Content In Indonesian ELT Textbooks. Jurnal Pendidikan Bahasa 9(1), 92-102.

Reigle, L. J. (2011). The Role of Pragmatic Competence in Second Language Acquisition. All Graduate Reports and Creative Universiti Teknologi MARA, Vol. 5, No. 3, 2021 
Eka Siswantara, Kamisah Ariffin

\section{Analysing the Pragmatic Content in the Conversation Sections in Indonesian ELT Textbooks}

Projects, 78 .

Ren, W., \& Han, Z. (2016). The representation of pragmatic knowledge in recent ELT textbooks. ELT Journal, 70(4), 424-434.

Richards, J.C. (2001). Curriculum development in language teaching. Cambridge: CUP.

Roever, C. (2009). Teaching and testing Pragmatics. In H. Long and J. Doughty (eds.) The Handbook of Language Teaching. Oxford: Wiley-Blackwell Publishing, 560-577.

Searle, J. R. (1968). Austin on Locutionary and Illocutionary Acts John. The Philosophical Review, 77(4), 405-424.

Searle, J. R. (1979). Expression and meaning: Studies in the theory of speech acts. Cambridge University Press.

Sudaryanto. (1993). Metode dan aneka teknik analisis bahasa: pengantar penelitian wahana kebudayaan secara linguistis. Duta Wacana University Press.

Suryoputro, G. G., \& Suyatno. (2017). Pragmatics role in the EFL teaching to Indonesian junior and senior high school students. International Journal of Language and Linguistics, 4(2), 53-59.

Thomas, J. (1983). Cross-cultural pragmatic failure. Applied Linguistics, 4(2), 91-112.

Thomas, J. (2014). Meaning in interaction. An introduction to pragmatics. Longman.

Thomson, A. J., \& Martinet, A. V. (2001). A Practical English Grammar. Oxford: Oxford University Press.

Ton Nu, A. T. \& Murray, J. (2020). Pragmatic Content in EFL Textbooks: An Investigation into Vietnamese National Teaching Materials. TESL-EJ: The Electronic Journal for English as a Second Language, 24 (3), 1-28.

Vanderveken, D. (2009). Meaning and speech acts: Volume 2, formal semantics of success and satisfaction. Cambridge University Press.

Widiati, U., Rohmah, Z., \& Furaidah. (2015). Bahasa Inggris Kelas XII SMA/MA/SMK/MAK. Jakarta: Pusat Kurikulum dan Perbukuan, Balitbang, Kemendikbud.

Widiati, U., Rohmah, Z., \& Furaidah. 2017). Bahasa Inggris Kelas X SMA/MA/SMK/MAK. Jakarta: Pusat Kurikulum dan Perbukuan, Balitbang, Kemendikbud.

Yule, G. (1996). Pragmatics. Oxford University Press.

Yusefi, K., Gowhary, H., Azizifar, A., \& Esmaeili, Z. (2015). A Pragmatic Analysis of Thanking Strategies Among Kurdish Speakers of Ilam Based on Gender and Age. Procedia - Social and Behavioral Sciences, 199, 211-217. 